\title{
To Some Extent
}

National Cancer Institute

\section{Source}

National Cancer Institute. To Some Extent. NCI Thesaurus. Code C121915.

An indication that something has been accomplished to some degree or has resulted in some amount of satisfaction. 